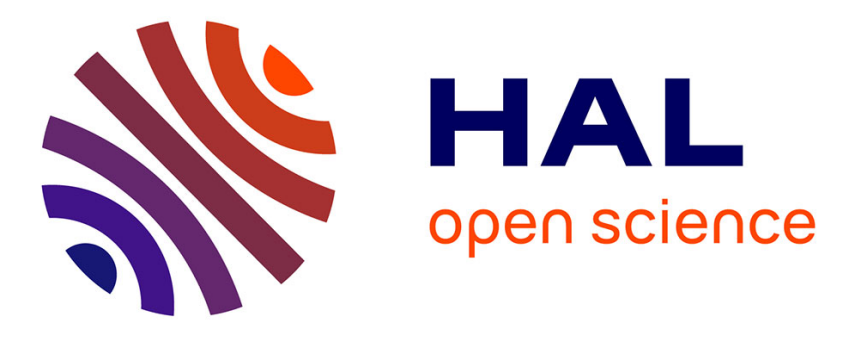

\title{
Probing the Adhesion of the Common Freshwater Diatom Nitzschia palea at the Nanoscale
}

Martin Laviale, Audrey Beaussart, Joey Allen, Fabienne Quilès, Sofiane El-Kirat-Chatel

\section{- To cite this version:}

Martin Laviale, Audrey Beaussart, Joey Allen, Fabienne Quilès, Sofiane El-Kirat-Chatel. Probing the Adhesion of the Common Freshwater Diatom Nitzschia palea at the Nanoscale. ACS Applied Materials \& Interfaces, 2019, 11 (51), pp.48574-48582. 10.1021/acsami.9b17821 . hal-02396296

\section{HAL Id: hal-02396296 https://hal.science/hal-02396296}

Submitted on 13 Nov 2020

HAL is a multi-disciplinary open access archive for the deposit and dissemination of scientific research documents, whether they are published or not. The documents may come from teaching and research institutions in France or abroad, or from public or private research centers.
L'archive ouverte pluridisciplinaire HAL, est destinée au dépôt et à la diffusion de documents scientifiques de niveau recherche, publiés ou non, émanant des établissements d'enseignement et de recherche français ou étrangers, des laboratoires publics ou privés. 


\title{
Probing the Adhesion of the Common Freshwater Diatom Nitzschia palea at the Nanoscale.
}

\author{
Martin Laviale, ${ }^{1 \S}$ Audrey Beaussart, ${ }^{2 \S}$ Joey Allen, ${ }^{1 \dagger}$ Fabienne Quilès, ${ }^{3}$ Sofiane El-Kirat- \\ Chatel $^{3^{*}}$
}

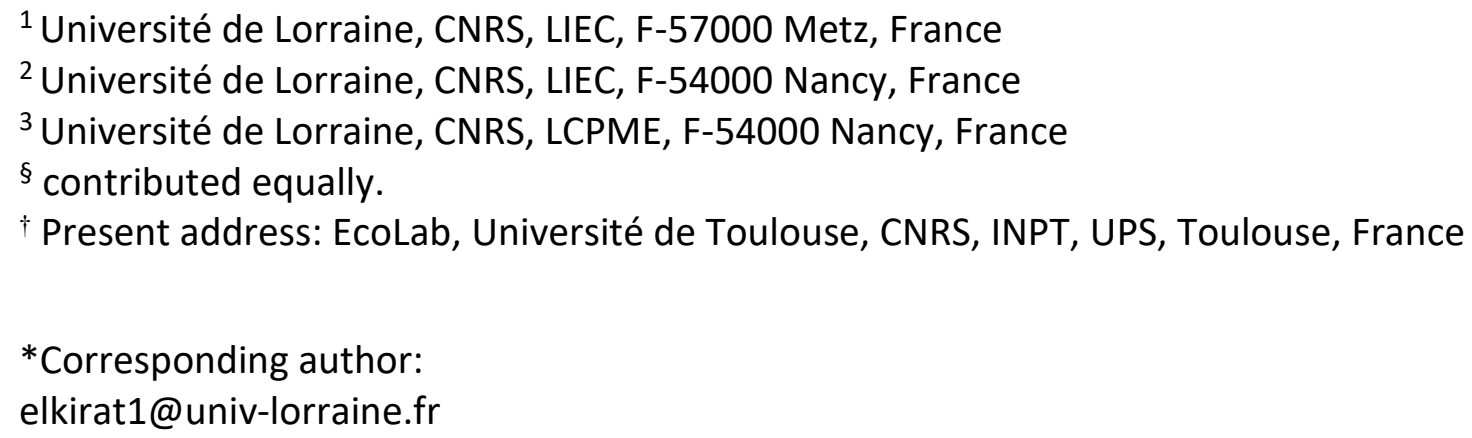

Keywords: diatom adhesion, AFM, single-cell force spectroscopy, chemical force spectroscopy, Raman spectroscopy, phototrophic biofilm, Nitzschia palea 


\section{ABSTRACT}

Freshwater biofilms play an essential ecological role but they also adversely affect human activities through undesirable biofouling of artificial submerged structures. They form complex aggregates of microorganisms that colonize any type of substratum. In phototrophic biofilms, diatoms dominate in biomass and produce copious amount of extracellular polymeric substances (EPS) that make them efficient early colonizers. Therefore, a better understanding of diatoms adhesive properties is essential to develop new anti-biofouling strategies. In this context, we used atomic force microscopy (AFM) to decipher the topography and adhesive mechanisms of the common freshwater diatom Nitzschia palea. Images in physiological conditions revealed typical ultrastructural features with a few nanometers resolution. Using single-cell force spectroscopy, we showed that $N$. palea strongly adhere to hydrophobic surfaces as compared to hydrophilic ones. Chemical force spectroscopy with hydrophobic tips further confirmed that adhesion is governed by surface-associated hydrophobic EPS distributed in clusters at the frustule surface, and mostly composed of (glyco)-lipids as revealed by Raman spectroscopy. Collectively, our results demonstrate that AFM-based nanoscopy, combined with Raman spectroscopy, is a powerful tool to provide new insights into the adhesion mechanisms of diatoms. 


\section{INTRODUCTION}

Phototrophic biofilms are essential ecological players in all freshwater environments, acting at the interface between the water column and any immersed surface and contributing to the global biogeochemical fluxes. ${ }^{1}$ Besides their role in aquatic ecosystems, biofilms cause biofouling of industrial structures, therefore increasing drag forces and impacting human activities with an estimated global economic loss of US\$ 277 million per year. ${ }^{2-4}$ They are formed by complex aggregates of microorganisms including fungi, bacteria, protozoa and microalgae, among which diatoms often dominate the biomass. ${ }^{1,5-6}$ Diatoms are a diverse and abundant group of eukaryotic unicellular photosynthetic organisms, motile or nonmotile and characterized by the presence of a highly ornamented siliceous exoskeleton called frustule. They are known to produce copious amount of extracellular polymeric substances (EPS) which can represent between 50 and $90 \%$ of total organic biofilm biomass, depending on environmental conditions. ${ }^{7}$ EPS are involved in direct adhesion, locomotion and colony formation. ${ }^{8-10}$ Their production has been highlighted as the main factor explaining why diatoms are such efficient early colonizers, independently of the nature of the immersed substrates. ${ }^{11-12}$ Despite the importance of freshwater diatoms in ecology and biofouling, the mechanisms governing their adhesion remain poorly investigated as compared to marine diatoms or other common fouling microorganisms. ${ }^{6,9,13-15}$ In particular, very little is known on how freshwater diatom cells interact with different substrates, although these organisms are likely to encounter in situ numerous microhabitats of various chemical nature, potentially influencing their adhesion capabilities. ${ }^{16-19}$ However, understanding the specific interactions that individual cells maintain with the substrate or with other cells is required when one wants to control biofilm formation. Indeed, the 
adhesion of each individual cell plays a role in the general structure of the biofilm (e.g. in terms of patchiness, thickness or biodiversity), ultimately influencing its functioning. ${ }^{20}$

In the last two decades, atomic force microscopy (AFM) has increasingly contributed to deciphering molecular mechanisms governing microbial adhesion. ${ }^{21-23}$ Here we used AFMbased methodologies to decipher the topography and adhesive properties of the common freshwater diatom Nitzschia palea at the nanoscale. We first used AFM imaging to unravel typical morphological features of live cells. Then, we used single-cell force spectroscopy (SCFS) to probe $N$. palea adhesion towards substrates of different chemical properties. Our results demonstrate that $N$. palea presents strong adhesion forces towards hydrophobic surfaces. The distribution of hydrophobic features was also probed at the molecular level by chemical force microscopy (CFM), revealing that adhesive EPS are forming adhesive patches on the cell surface. Finally, we used Raman microspectroscopy -a label-free and nondestructive method- to characterize the biochemical composition of diatoms in physiological conditions. ${ }^{24}$ Raman spectra suggest that EPS promoting $N$. palea adhesion are mostly (glyco)-lipids. Overall, our work demonstrates that AFM combined with Raman spectroscopy is a valuable approach to decipher adhesive properties of diatoms.

\section{RESULTS AND DISCUSSION}

Nanoscale imaging of $\boldsymbol{N}$. palea cell surface. We first imaged the ultrastructure of $N$. palea using AFM in PeakForce mode. Figure 1 shows images obtained in air (Fig. 1a-c) and in physiological conditions i.e. in liquid culture medium (Fig. 1e-g). A diatom frustule is composed of two thecae (epi/hypo-theca) that overlap as a Petri dish. Each theca consists of a silica valve and several girdle bands outlining the cell, both ornamented in a highly complex species-specific manner. $N$. palea is a pennate diatom, which exhibits a bilateral symmetry. 
Cells presented elongated shapes with long axis of $15.7 \pm 1.9 \mu \mathrm{m}$ and short axis of $4.2 \pm 0.8$ $\mu \mathrm{m}$ (Fig. 1a and d, lengths measured on 12 cells). Images of entire cells showed that $N$. palea valves are isopolar and linear-lanceolate: sides along the long axis are parallel and taper sharply on both ends, thereby delimiting similarly shaped (subcapitate) apices. The cell surface presented stripes aligned with the short axis. At higher magnification, images revealed that stripes correspond to striae of pores arranged in lines parallels to the short axis. The distance between two pores of the same line was about $60 \mathrm{~nm}$ and the inter-line distance was about $200 \mathrm{~nm}$. As most pennate diatoms, N. palea cells also possess a slit along the long axis called raphe and which was visible at the margin of the valve on high-resolution images (Fig. 1f, white arrow). This topographical analysis is in line with the previous descriptions of this species. ${ }^{25-26}$ Moreover, the striae were barely visible at lower magnification, probably due to the presence of a layer of mucilage, mostly composed of EPS. ${ }^{27}$ It was also visible at higher magnification as all pores seemed obstructed by this mucilage. EPS layer is known to be extruded by the cell through the pores and the raphe, and to encapsulate the whole frustule. ${ }^{9,28}$

Morphological differences were observed between images obtained in air and liquid conditions. Cross sections revealed that cells imaged in air presented a smaller height than cells imaged in liquid ( $1.8 \pm 0.6 \mu \mathrm{m}$ vs $3.3 \pm 0.2 \mu \mathrm{m}$, respectively), which probably reflect cells collapsing during the drying process (Fig. 1d,h). Such artefact has been reported for other species. ${ }^{29-30}$ Here, we showed that the drying step affects both the morphology of the whole cell and the pores as dried cells presented asymmetric deformed shapes arboring ovoidal pores whereas the latest were spherical with a diameter of $\sim 120 \mathrm{~nm}$ for cells maintained in liquid. Drying of the mucilage filling the pores also appears through changes in the root mean square $(\mathrm{rms})$ cell surface roughness, which increases from $3.85 \pm 0.57 \mathrm{~nm}$ to $6.61 \pm$ 
$0.32 \mathrm{~nm}$ (calculated on $1 \mu \mathrm{m} \times 1 \mu \mathrm{m}$ areas) for cells imaged in liquid and in air, respectively. Together with previous studies, these results demonstrate that AFM, performed in physiological conditions, is required to assess true topographical characterization of diatoms with limited artefacts. ${ }^{27,29,31-34}$

N. palea cells adhere preferentially on hydrophobic surfaces. As diatoms are known to colonize surfaces of various physico-chemical properties, ${ }^{16,18}$ we compared the adhesive properties of $N$. palea cells towards hydrophobic and hydrophilic surfaces. We first investigated the macroscopic adhesion of diatoms, i.e. at the population scale. For that, cells were deposited on gold substrates of $113 \mathrm{~mm}^{2}$ presenting similar physical properties (in terms of e.g. roughness and stiffness) but which differ in their chemical properties, i.e. functionalized with $\mathrm{CH}_{3}$ or $\mathrm{OH}$ terminated alkanethiols to obtain surfaces with hydrophobic and hydrophilic self-assembled monolayer (SAM), respectively. Surface wettability was further confirmed by water contact angle measurements. Hydrophobic and hydrophilic surfaces presented water contact angles of $\sim 105^{\circ}$ and $\sim 20^{\circ}$, respectively, as measured by static sessile drop method. After $4 \mathrm{~h}$ in the presence of $3 \times 10^{5}$ cells, surfaces were gently rinsed to remove loosely- and non-adhered cells before optical imaging. The number of $N$. palea adhered cells was 30 times higher on hydrophobic surfaces ( 720 adhered cells. $\mathrm{mm}^{-2}$ ) than on hydrophilic surfaces ( 24 adhered cells.mm²; Fig. 2). This analysis suggests that $N$. palea preferentially adhere on hydrophobic substrates and correlates with phenotypes described for other raphid diatoms: the freshwater species Nitzschia amphibia ${ }^{18}$ and the marine species Phaeodactylum tricornutum, ${ }^{35}$ Seminavis robusta, ${ }^{19}$ Navicula perminuta,${ }^{36-37}$ Navicula incerta, ${ }^{38}$ Craspedostauros australis, ${ }^{37}$ and Amphora coffeaeformis. ${ }^{37,39}$ 
AFM-based analysis of $\boldsymbol{N}$. palea adhesion. Beyond the possibility to image biological samples at high resolution, AFM has recently emerged as a powerful tool to decipher physico-chemical properties of microbial cells. ${ }^{22,40}$ Here we used two AFM force spectroscopy modes to gain a better insight into the mechanisms governing $N$. palea adhesion: i) single-cell force spectroscopy (SCFS) to probe the adhesion of whole cells towards hydrophobic and hydrophilic surfaces (Fig. 3a); and ii) chemical force microscopy (CFM) to quantify the hydrophobic/hydrophilic balance of the cell surface and map the distribution of adhesive molecules with few nanometers lateral resolution (Fig. 3b). For SCFS, tipless cantilevers coated with polydopamine -a biocompatible glue known to maintain cell viability- $^{41-42}$ were used to pick up $N$. palea cells and measure individual force-distance curves. The originality of the methodology resides in the attachment of a single cell, allowing real comparison of the affinity of living diatoms for different surfaces under external applied forces. For CFM, hydrophobic and hydrophilic probes were obtained by functionalizing goldcoated AFM tips with thiols terminated with methyl or hydroxyl groups and the probes were used to record force-volume maps at the surface of cells immobilized on the substrate.

SCFS reveals strong adhesion of $\boldsymbol{N}$. palea on hydrophobic surface. To quantify the adhesion strength of individual $N$. palea cells, we first used SCFS to probe cell adhesion on different surfaces. Figure 4 shows the adhesion force and rupture length histograms together with representative force-distance curves obtained for six different cells probed on hydrophobic and hydrophilic surfaces. On hydrophobic surfaces, most force curves presented adhesive peaks (adhesion frequency $~ 100 \%$ ) with an adhesion force ranging from 250 to $1500 \mathrm{pN}$ and rupture distance ranging from 250 to $4000 \mathrm{~nm}$ (Fig. 4a). The corresponding force-distance curves signatures displayed multiple peaks documenting the unfolding of biopolymers, i.e. EPS macromolecules. These EPS are exposed the cell surface 
to promote adhesion and are unfolded under external load applied here through the cantilever retraction. These features are reminiscent of the adhesive properties described for the marine diatom Navicula sp. ${ }^{43}$ The adhesion frequency was significantly lower on hydrophilic substrates with all cells presenting an adhesive frequency below $50 \%$ and half of the cells displaying no adhesion at all (Fig. 4b; cells 1-3). For cells 4-6, adhesion forces ranged from 100 to $1000 \mathrm{pN}$ and rupture distances from 100 to $3500 \mathrm{~nm}$. When adhesion was detected on hydrophilic surfaces, the force-distance curves featured simpler signatures than observed on hydrophobic surface, with 1-3 peaks. This behaviour contrasts with that reported for Navicula sp. where similar adhesion was recorded on both hydrophobic and hydrophilic substrates. ${ }^{43}$

The adhesive properties described above correspond to the phenotype observed for most cells. One of the advantages of using single-cell technique is that isolated behaviour, which would be hidden in macroscopic tests, can be highlighted. Here, some heterogeneities were detected in the cell population with cells presenting hyper-adhesive or non-adhesive phenotypes. Figure 5 shows the results obtained for two hyper-adhesive cells for which the adhesion frequency reached $100 \%$ on hydrophobic surfaces and was $>70 \%$ on hydrophilic surfaces. By contrast, for cells presenting non-adhesive phenotypes, almost no adhesive events were recorded on both hydrophobic and hydrophilic surfaces (Fig. 6). In the case of Navicula sp. previously reported, cells adhered similarly to hydrophobic and hydrophilic surfaces, it was therefore not possible to determine whether the adhesion was mediated by different EPS or only one type presenting affinity regions for both hydrophobic and hydrophilic substrates. ${ }^{43}$ Here, the heterogeneity observed suggests that: i) some cells seem not to produce adhesive EPS, surely linked to their growth state, and ii) other cells are able 
to produce various types of EPS as adhesion to hydrophilic substrates is not always coincident with hydrophobic adhesion and leads to different force signatures.

EPS are not homogeneously distributed at the cell surface. We then wanted to decipher the precise distribution of the adhesive biomolecules at the surface of $N$. palea cells and to determine the physico-chemical properties of these compounds. Figure 7 shows forcevolume maps of $2 \times 2 \mu \mathrm{m}^{2}$ recorded at the surface of $N$. palea cells with AFM tips decorated with methyl or hydroxyl groups (Fig. S1 presents similar data obtained on different cell locations). When cells were probed with hydrophobic tips (Fig. 7a-d), $20 \%$ of force curves displayed adhesive events, corresponding to a surface density of $\sim 50$ hydrophobic adhesive molecules per $\mu \mathrm{m}^{2}$ at the center of the diatom cell. Some cells featured higher adhesion with up to $\sim 80 \%$ of force curves corresponding to adhesive events (Fig. S1 a and b). This correlates with the hyper-adhesive phenotype observed during SCFS measurements (see above). Most hydrophobic forces ranged from 100 to $500 \mathrm{pN}$ and the rupture lengths were distributed from 100 to $4000 \mathrm{~nm}$. The force signatures revealed multiple peaks, some with regular sawtooth patterns, suggesting that different domains of biopolymers are stretched and unfolded when subjected to external force applied with the hydrophobic tip. Similar features were reported for the marine diatoms Phaeodactylum tricornutum, ${ }^{44}$ Toxarium undulatum, ${ }^{45-46}$ Craspedostauros australis and the freshwater diatom Pinnularia viridis. ${ }^{27}$ Mapping with hydrophilic tips resulted in a lower adhesion frequency (6-8 \%), confirming that N. palea cells have more tendency to interact with hydrophobic entities (Fig. 7e-h). Here again, some cells presented hyper-adhesive phenotypes with $20 \%$ of force curves showing adhesion between the hydrophilic tips and the cell surface (Fig. S1 $g$ and h). The adhesion force and rupture lengths ranges were comparable to the results obtained with hydrophobic tips but the force signatures presented only simple peaks documenting a single extension 
without unfolding of intramolecular domains. With both hydrophobic and hydrophilic tips, the distribution of adhesive events seemed to form clusters suggesting that EPS are grouped as adhesive patches on $N$. palea surface. Moreover, recording maps at different cell locations revealed that EPS accumulate more at the cell center than at the apexes (Fig. S1).

(Glyco)-lipids is the major EPS of $\boldsymbol{N}$. palea cells. EPS macromolecules can present different domains or regions to mediate adhesion to a wide range of surfaces. ${ }^{43,47}$ Here, our SCFS and CFM results suggest that $N$. palea produces mostly EPS with affinity for hydrophobic substrates, but that other EPS types, which permit adhesion on hydrophilic supports, are also present but less abundant. In diatoms, hydrophobic interactions can be promoted by hydrophobic polysaccharides, proteins, proteoglycans and lipids whereas adhesion to hydrophilic substrates involves acidic-neutral polysaccharides. ${ }^{10,43,46,48-53}$ Here, we used Raman microspectroscopy to obtain chemical information on the EPS driving N. palea adhesion (Fig. 8). Spectra were recorded on isolated and aggregated cells, on which EPS are expected to be present in high quantity to ensure cohesiveness. Assignments were made according to previous Raman studies on different reference molecules and on other microalgae. ${ }^{54-57}$ The bands mainly correspond to proteins, lipids and carbohydrates. Such composition was already reported for other diatoms. ${ }^{58}$ The signature of the amorphous silica from the frustule was not resolved due to weak intensities of their scattering bands. ${ }^{59-61}$ The spectral fingerprints were very different from individual cells to aggregates. The spectra of single cells showed bands at 1303, 1454 and $1735 \mathrm{~cm}^{-1}$ assigned to fatty esters. No specific band from possible unsaturated fatty acids was observed in the region between 3000 and $3050 \mathrm{~cm}^{-1}$, indicating that they were mostly composed of saturated alkyl chains. Depending on the position of the recorded spectrum, these bands have different intensities, indicating a non-homogeneous distribution of the biomolecules as suggested also by CFM (see above). 
Bands at $1003 \mathrm{~cm}^{-1}$, between 1200 and $1250 \mathrm{~cm}^{-1}$, and between 1600 and $1700 \mathrm{~cm}^{-1}$ were assigned to proteins. Few carbohydrates were observed in the spectra in region 1000-1150 $\mathrm{cm}^{-1}$. Carbohydrates are usually very complex and highly branched molecules that could be involved in hydrophobic interactions through an enrichment in methyl groups of the terminal residues such as rhamnose, fucose and xylose. ${ }^{10,62}$ On aggregated cells, the main bands were at $1302,1440,1656,1730$ and $1746 \mathrm{~cm}^{-1}$, and assigned to triacylglycerol lipids. ${ }^{54}$ A band at $3008 \mathrm{~cm}^{-1}$ assigned to $\mathrm{C}-\mathrm{H}$ stretching on $\mathrm{C}=\mathrm{C}$ bonds was also observed indicating the occurrence of unsaturated $\mathrm{C}=\mathrm{C}$ bonds in their alkyl chains. Overlapped bands in regions $800-900 \mathrm{~cm}^{-1}$ and $1000-1200 \mathrm{~cm}^{-1}$ were assigned to carbohydrate moieties possibly linked to the lipids forming hydrophobic EPS (it was not possible to assign the bands to specific carbohydrates). Methylated sugars were not detected (bands at $1440-1470 \mathrm{~cm}^{-1}$ for $\mathrm{CH}_{3}$ bending and $2815-2850 \mathrm{~cm}^{-1}$ for $\mathrm{CH}_{3}$ symmetric stretching), suggesting that the adhesion mechanisms of $N$. palea on hydrophobic substrates differ from that reported for $P$. tricornutum..$^{10}$ Altogether, these results indicate that during exponential growth, $N$. palea adhesion is mostly promoted by (glyco)-lipids which are not homogenously distributed at the cell surface. As previously reported, this composition may change depending on the cell growth stage or environmental conditions. ${ }^{10,62,63}$

\section{CONCLUSIONS}

Freshwater biofilms are involved in ecosystem cycles and are also responsible for biofouling of industrial structures. ${ }^{1-4,6}$ Diatoms are major actors of freshwater biofilms, therefore understanding the mechanisms that governs their adhesion is a key challenge to control ecosystem equilibrium and to develop new anti-biofouling strategies. ${ }^{9,11-12}$ The application of AFM and Raman spectroscopy to biological samples gives a new vision of the 
physico-chemical properties governing interactions at the interface between microbial cells and their environment. ${ }^{22-24}$ Here, we have used AFM combined with Raman spectroscopy to decipher the adhesion of the freshwater diatom N. palea. The ultrastructure of N. palea cell surface was revealed by AFM imaging and linked to the exposure of adhesive EPS. Using SCFS, we have shown that $N$. palea diatoms adhere strongly on hydrophobic surfaces and this adhesion involves the unfolding of surface-associated biopolymers. By contrast, the adhesion on hydrophilic surface is lower and seems to involve polymers of different nature, i.e. without unfoldable domains. At higher resolution, the use of AFM tips decorated with functional groups revealed that adhesive EPS form adhesive patches on the cell surface. Finally, through Raman spectroscopy analysis, the major EPS of N. palea have been identified as (glyco)-lipids. To conclude, this work provides quantitative information on diatoms adhesion and complements the traditional methods (adhesion tests and electron microscopy) used to characterize diatoms surface properties. The multi-scale approach used here allows the deciphering of adhesive properties in conditions close to natural environments, i.e. with living cells subjected to external forces. We anticipate that the application of such methodology to other diatoms will contribute to a better understanding of surface colonization and biofilm formation in streams and rivers.

\section{METHODS}

Microorganisms and growth conditions. The N. palea strain, initially isolated from biofilm in the river Garonne (South-West France), was cultivated in the artificial liquid culture medium $\mathrm{COMBO}^{64}$ in a growth cabinet $\left(20^{\circ} \mathrm{C}, 50 \mu \mathrm{mol}\right.$ photons $\left./ \mathrm{m}^{2} / \mathrm{s}\right)$. The culture was maintained in exponential growth phase by weekly dilution in fresh medium. 
Preparation of hydrophobic and hydrophilic surfaces. For hydrophobic and hydrophilic model surfaces, glass coverslips $(\varnothing 12 \mathrm{~mm}$ ) were coated with $\sim 10 \mathrm{~nm}$ of $\mathrm{Cr}$ and $\sim 30 \mathrm{~nm}$ of $\mathrm{Au}$, cleaned by UV/ozone for $15 \mathrm{~min}$ and then self-assembled monolayers of alkanethiols were formed by immersion overnight in the dark in a solution of $1 \mathrm{mM}$ 1-dodecanethiol (Sigma) or $1 \mathrm{mM}$ 11-mercapto-1-undecanol, respectively. Before use, surfaces were rinsed with ethanol and dried with $\mathrm{N}_{2}$. Surface wettability was determined by static water contact angle measurements.

Adhesion assay. $300 \mu \mathrm{L}$ of an exponentially growing $N$. palea suspension at $1 \times 10^{6}$ cells. $\mathrm{mL}^{-1}$ were deposited on hydrophobic and hydrophilic surfaces of $113 \mathrm{~mm}^{2}$ size. After $4 \mathrm{~h}$, nonadhered cells were removed by gentle rinsing in 3 consecutive baths of fresh COMBO medium and surfaces were transferred to the inverted microscope (DMi8, Leica Microsystems) equipped with a Hamamatsu digital camera (Orca-flash4.0lt) for imaging.

Atomic Force microscopy imaging. $300 \mu \mathrm{L}$ of $N$. palea suspension were deposited on hydrophobic surfaces and let to settle for 3 hours. For dry imaging, surfaces were rinsed 3 times by gentle immersion in ultrapure water and dried overnight at $37^{\circ} \mathrm{C}$ before imaging. For liquid imaging, surfaces were gently rinsed in COMBO medium and then transferred to the AFM liquid set-up while avoiding dewetting of the sample. For both conditions, images were obtained in peak force tapping mode of a Dimension Icon AFM (Bruker corporation, Santa Barbara, CA), using SNL cantilevers (Bruker corporation, nominal spring constant of $\sim 0.24 \mathrm{~N} \mathrm{~m}^{-1}$ ) with a maximum applied force of $5 \mathrm{nN}$.

AFM-based single-cell force spectroscopy. SCFS measurements were performed at room temperature $\left(20^{\circ} \mathrm{C}\right)$ in $\mathrm{COMBO}$ medium using a Bioscope Resolve AFM (Bruker corporation, Santa Barbara, CA) and tipless cantilevers (NP-O10 Microlevers, Bruker Corporation, nominal 
spring constant of $\sim 0.06 \mathrm{~N} \mathrm{~m}^{-1}$ ) coated with polydopamine by immersion for $1 \mathrm{~h}$ in a solution of Tris buffer (10 mM, pH 8.5) containing $4 \mathrm{mg} \cdot \mathrm{mL}^{-1}$ dopamine hydrochloride. The spring constants of the cantilevers were measured using the thermal noise method. Hydrophobic and hydrophilic surfaces were attached with double-sided tape at the bottom edges of a glass Petri dish and $50 \mu \mathrm{L}$ of $N$. palea cell suspension were deposited at the center of the Petri dish containing $5 \mathrm{~mL}$ of fresh COMBO medium. For single cell bioprobe, the tipless cantilever was brought into contact with an isolated cell and then retracted and transferred over hydrophobic and hydrophilic surfaces for force measurements. Multiple force curves were recorded alternatively at different spots of the two model surfaces using a maximum applied force of $1.5 \mathrm{nN}$, a contact time of $50 \mathrm{~ms}$ and a retraction speed of $2000 \mathrm{~nm} \cdot \mathrm{s}^{-1}$. Adhesion histograms and rupture length histograms were obtained by calculating on each curve the maximum adhesion peak and the last rupture event, respectively.

AFM-based chemical force spectroscopy. CFM measurements were performed at room temperature $\left(20^{\circ} \mathrm{C}\right)$ in $\mathrm{COMBO}$ medium using a Bioscope Resolve AFM (Bruker corporation, Santa Barbara, CA) and gold coated AFM tips (NPG-10 Microlevers, Bruker Corporation, nominal spring constant of $\sim 0.06 \mathrm{~N} \mathrm{~m}^{-1}$ ). For tips functionalization, cantilevers were immersed overnight in the dark in $1 \mathrm{mM}$ 1-dodecanethiol (Sigma) or $1 \mathrm{mM}$ 11-mercapto-1undecanol to obtain hydrophobic or hydrophilic tips, respectively. Before use, cantilevers were rinsed with ethanol and dried with $\mathrm{N}_{2}$. Force-volumes of $32 \times 32$ pixels $^{2}$ were recorded on different areas of $2 \times 2 \mu \mathrm{m}^{2}$ at the surface of $N$. palea cells previously deposited on a hydrophobic surface attached at the bottom of a glass Petri dish. The cell surface was located by optical microscopy and force-distance curves were recorded with a maximum applied force of $500 \mathrm{pN}$, a contact time of $250 \mathrm{~ms}$ and a retraction speed of $5000 \mathrm{~nm} \cdot \mathrm{s}^{-1}$. 
Adhesion maps, adhesion histograms and rupture length histograms were obtained by calculating the last rupture event on each curve.

Raman microspectroscopy. Raman spectra were collected in the range of $600-3050 \mathrm{~cm}^{-1}$ with a Renishaw inVia Qontor spectrometer equipped with a Leica confocal microscope. Measurements were recorded using an Olympus $\times 60$ water immersion objective. The instrument was equipped with an Edge filter to eliminate the Rayleigh scattering, 2400 grooves per millimeter grating, and the Renishaw Centrus detector. The excitation source was at $532 \mathrm{~nm}$ and the power was $250 \mathrm{~mW}$. $200 \mu \mathrm{L}$ of $N$. palea suspension were laid on a Ge disk and the spectra were recorded in situ. Acquisition time was $30 \mathrm{sec}$. Spectra were base line corrected with a polynomial function from the Wire 5.2 software.

\section{SUPPORTING INFORMATION}

Figure S1: CFM on different areas of diatom cells.

\section{ACKNOWLEDGEMENTS}

This work was financially supported by Université de Lorraine and CNRS through projects AQUAFUN (Action de site Mirabelle) and DIADHEPS (OTELO interdisciplinaire). Authors are grateful to Loïc TEN-HAGE for providing the diatom culture and David HEUDRE for sharing his knowledge on diatom taxonomy.

\section{REFERENCES}

1. Battin, T. J.; Besemer, K.; Bengtsson, M. M.; Romani, A. M.; Packmann, A. I. The Ecology and Biogeochemistry of Stream Biofilms. Nat. Rev. Microbiol. 2016, 14, 251-263.

2. Nakano, D.; Strayer, D. L. Biofouling Animals in Fresh Water: Biology, Impacts, and Ecosystem Engineering. Front. Ecol. Environ. 2014, 12, 167-175.

3. Andrewartha, J.; Perkins, K.; Sargison, J.; Osborn, J.; Walker, G.; Henderson, A.; Hallegraeff, G. Drag Force and Surface Roughness Measurements on Freshwater Biofouled Surfaces. Biofouling 2010, 26, 487-496.

4. Perkins, K. J.; Andrewartha, J. M.; McMinn, A.; Cook, S. S.; Hallegraeff, G. M. Succession and Physiological Health of Freshwater Microalgal Fouling in a Tasmanian Hydropower Canal. Biofouling 2010, 26, 637-644. 
5. Sabater, S.; Guasch, H.; Ricart, M.; Romani, A.; Vidal, G.; Klunder, C.; Schmitt-Jansen, M. Monitoring the Effect of Chemicals on Biological Communities. The Biofilm as an Interface. Anal. Bioanal. Chem. 2007, 387, 1425-1434.

6. Salta, M.; Wharton, J. A.; Blache, Y.; Stokes, K. R.; Briand, J. F. Marine Biofilms on Artificial Surfaces: Structure and Dynamics. Environ. Microbiol. 2013, 15, 2879-2893.

7. Nielsen, P. H.; Jahn, A.; Palmgren, R. Conceptual Model for Production and Composition of Exopolymers in Biofilms. Water Sci. Technol. 1997, 36, 11-19.

8. Hoagland, K. D.; Rosowski, J. R.; Gretz, M. R.; Roemer, S. C. Diatom Extracellular Polymeric Substances: Function, Fine Structure, Chemistry and Physiology. J. Phycol. 1993, 29, 537566.

9. Molino, P. J.; Wetherbee, R. The Biology of Biofouling Diatoms and Their Role in the Development of Microbial Slimes. Biofouling 2008, 24, 365-379.

10. Abdullahi, A. S.; Underwood, G. J. C.; Gretz, M. R. Extracellular Matrix Assembly in Diatoms (Bacillariophyceae). V. Environmental Effects on Polysaccharide Synthesis in the Model Diatom, Phaeodactylum tricornutum. J. Phycol. 2006, 42, 363-378.

11. Cooksey, K. E.; Wigglesworth-Cooksey, B. Adhesion of Bacteria and Diatoms to Surfaces in the Sea: A Review. Aquat. Microb. Ecol. 1995, 9, 87-96.

12. Wetherbee, R.; Lind, J. L.; Burke, J.; Quatrano, R. S. Minireview-the First Kiss: Establishment and Control of Initial Adhesion by Raphid Diatoms. J. Phycol. 1998, 34, 9-15.

13. Landoulsi, J.; Cooksey, K. E.; Dupres, V. Review-Interactions between Diatoms and Stainless Steel: Focus on Biofouling and Biocorrosion. Biofouling 2011, 27, 1109-1124.

14. Richard, C.; Mitbavkar, S.; Landoulsi, J. Diagnosis of the Diatom Community Upon Biofilm Development on Stainless Steels in Natural Freshwater. Scanning 2017, 2017, 5052646.

15. Callow, J. A.; Callow, M. E. Trends in the Development of Environmentally Friendly FoulingResistant Marine Coatings. Nat. Commun. 2011, 2, 244.

16. Bergey, E. A.; Cooper, J. T.; Phillips, B. C. Substrate Characteristics Affect Colonization by the Bloom-Forming Diatom Didymosphenia geminata. Aquat. Ecol. 2010, 44, 33-40.

17. Chen, L.; Weng, D.; Du, C.; Wang, J.; Cao, S. Contribution of Frustules and Mucilage Trails to the Mobility of Diatom Navicula sp. Sci. Rep. 2019, 9, 7342.

18. Sekar, R.; Venugopalan, V. P.; Satpathy, K. K.; Nair, K. V. K.; Rao, V. N. R. Laboratory Studies on Adhesion of Microalgae to Hard Substrates. Hydrobiologia 2004, 512, 109-116.

19. Thompson, S. E.; Taylor, A. R.; Brownlee, C.; Callow, M. E.; Callow, J. A. The Role of Nitric Oxide in Diatom Adhesion in Relation to Substratum Properties. J. Phycol. 2008, 44, 967976.

20. Laviale, M.; Prygiel, J.; Lemoine, Y.; Courseaux, A.; Creach, A. Stream Periphyton Photoacclimation Response in Field Conditions: Effect of Community Development and Seasonal Changes. J. Phycol. 2009, 45, 1072-1082.

21. Alsteens, D.; Beaussart, A.; El-Kirat-Chatel, S.; Sullan, R. M.; Dufrene, Y. F. Atomic Force Microscopy: A New Look at Pathogens. PLoS Pathog. 2013, 9, e1003516.

22. Dufrene, Y. F. Sticky Microbes: Forces in Microbial Cell Adhesion. Trends Microbiol. 2015, 23, 376-382.

23. Xiao, J.; Dufrene, Y. F. Optical and Force Nanoscopy in Microbiology. Nat. Microbiol. 2016, $1,16186$.

24. Parab, N. D. T.; Tomar, V. Raman Spectroscopy of Algae: A Review. J. Nanomed. Nanotechnol. 2012, 3, 1-7.

25. Hamsher, S.; Kopalová, K.; Kociolek, J. P.; Zidarova, R.; van de Vijver, B. The Genus Nitzschia on the South Shetland Islands and James Ross Island. Fottea 2016, 16, 79-102. 
26. Trobajo, R.; Clavero, E.; Chepurnov, V. A.; Sabbe, K.; Mann, D. G.; Ishihara, S.; Cox, E. J. Morphological, Genetic and Mating Diversity within the Widespread Bioindicator Nitzschia palea (Bacillariophyceae). Phycologia 2009, 48, 443-459.

27. Higgins, M. J.; Crawford, S. A.; Mulvaney, P.; Wetherbee, R. Characterization of the Adhesive Mucilages Secreted by Live Diatom Cells Using Atomic Force Microscopy. Protist 2002, 153, 25-38.

28. Bahulikar, R. A.; Kroth, P. G. Localization of EPS Components Secreted by Freshwater Diatoms Using Differential Staining with Fluorophore-Conjugated Lectins and Other Fluorochromes. Eur. J. Phycol. 2007, 42, 199-208.

29. Pletikapic, G.; Berquand, A.; Radic, T. M.; Svetlicic, V. Quantitative Nanomechanical Mapping of Marine Diatom in Seawater Using Peak Force Tapping Atomic Force Microscopy. J. Phycol. 2012, 48, 174-185.

30. Svetlicic, V.; Zutic, V.; Radic, T. M.; Pletikapic, G.; Zimmermann, A. H.; Urbani, R. Polymer Networks Produced by Marine Diatoms in the Northern Adriatic Sea. Mar. Drugs 2011, 9, 666-679.

31. Francius, G.; Tesson, B.; Dague, E.; Martin-Jezequel, V.; Dufrene, Y. F. Nanostructure and Nanomechanics of Live Phaeodactylum tricornutum Morphotypes. Environ. Microbiol. 2008, 10, 1344-1356.

32. Luís, A. T.; Hlúbiková, D.; Vaché, V.; Choquet, P.; Hoffmann, L.; Ector, L. Atomic Force Microscopy (AFM) Application to Diatom Study: Review and Perspectives. J. App. Phycol. 2017, 29, 2989-3001.

33. Almqvist, N.; Delamo, Y.; Smith, B. L.; Thomson, N. H.; Bartholdson, A.; Lal, R.; Brzezinski, M.; Hansma, P. K. Micromechanical and Structural Properties of a Pennate Diatom Investigated by Atomic Force Microscopy. J. Microsc. 2001, 202, 518-532.

34. Losic, D.; Short, K.; Mitchell, J. G.; Lal, R.; Voelcker, N. H. AFM Nanoindentations of Diatom Biosilica Surfaces. Langmuir 2007, 23, 5014-5021.

35. Stanley, M. S.; Callow , J. A. Whole Cell Adhesion Strength of Morphotypes and Isolates of Phaeodactylum tricornutum (Bacillariophyceae). Eur. J. Phycol. 2007, 42, 191-197.

36. Akesso, L.; Pettitt, M. E.; Callow, J. A.; Callow, M. E.; Stallard, J.; Teer, D.; Liu, C.; Wang, S.; Zhao, Q.; D'Souza, F.; et al. The Potential of Nano-Structured Silicon Oxide Type Coatings Deposited by Pacvd for Control of Aquatic Biofouling. Biofouling 2009, 25, 55-67.

37. Holland, R.; Dugdale, T. M.; Wetherbee, R.; Brennan, A. B.; Finlay, J. A.; Callow, J. A.; Callow, M. E. Adhesion and Motility of Fouling Diatoms on a Silicone Elastomer. Biofouling 2004, 20, 323-329.

38. Finlay, J. A.; Schultz, M. P.; Cone, G.; Callow, M. E.; Callow, J. A. A Novel Biofilm Channel for Evaluating the Adhesion of Diatoms to Non-Biocidal Coatings. Biofouling 2013, 29, 401-411.

39. Finlay, J. A.; Callow, M. E.; Ista, L. K.; Lopez, G. P.; Callow, J. A. The Influence of Surface Wettability on the Adhesion Strength of Settled Spores of the Green Alga Enteromorpha and the Diatom Amphora. Integr. Comp. Biol. 2002, 42, 1116-1122.

40. El-Kirat-Chatel, S.; Beaussart, A. Probing Bacterial Adhesion at the Single-Molecule and Single-Cell Levels by AFM-Based Force Spectroscopy. Methods Mol. Biol. 2018, 1814, 403414.

41. Beaussart, A.; El-Kirat-Chatel, S.; Sullan, R. M.; Alsteens, D.; Herman, P.; Derclaye, S.; Dufrene, Y. F. Quantifying the Forces Guiding Microbial Cell Adhesion Using Single-Cell Force Spectroscopy. Nat. Protoc. 2014, 9, 1049-1055.

42. Lee, H.; Dellatore, S. M.; Miller, W. M.; Messersmith, P. B. Mussel-Inspired Surface Chemistry for Multifunctional Coatings. Science 2007, 318, 426-430. 
43. Arce, F. T.; Avci, R.; Beech, I. B.; Cooksey, K. E.; Wigglesworth-Cooksey, B. A Live Bioprobe for Studying Diatom-Surface Interactions. Biophys. J. 2004, 87, 4284-4297.

44. Dugdale, T. M.; Willis, A.; Wetherbee, R. Adhesive Modular Proteins Occur in the Extracellular Mucilage of the Motile, Pennate Diatom Phaeodactylum tricornutum. Biophys. J. 2006, 90, 58-60.

45. Dugdale, T. M.; Dagastine, R.; Chiovitti, A.; Mulvaney, P.; Wetherbee, R. Single Adhesive Nanofibers from a Live Diatom Have the Signature Fingerprint of Modular Proteins. Biophys. J. 2005, 89, 4252-4260.

46. Dugdale, T. M.; Dagastine, R.; Chiovitti, A.; Wetherbee, R. Diatom Adhesive Mucilage Contains Distinct Supramolecular Assemblies of a Single Modular Protein. Biophys. J. 2006, 90, 2987-2993.

47. Becker, K. Exopolysaccharide Production and Attachment Strength of Bacteria and Diatoms on Substrates with Different Surface Tensions. Microb. Ecol. 1996, 32, 23-33.

48. Wigglesworth-Cooksey, B.; Cooksey, K. E. Can Diatoms Sense Surfaces?: State of Our Knowledge. Biofouling 1992, 5, 227-238.

49. Willis, A.; Chiovitti, A.; Dugdale, T. M.; Wetherbee, R. Characterization of the Extracellular Matrix of Phaeodactylum tricornutum (Bacillariophyceae): Structure, Composition, and Adhesive Characteristics. J. Phycol. 2013, 49, 937-949.

50. Poulsen, N.; Kroger, N.; Harrington, M. J.; Brunner, E.; Paasch, S.; Buhmann, M. T. Isolation and Biochemical Characterization of Underwater Adhesives from Diatoms. Biofouling 2014, 30, 513-523.

51.Stewart, T. J.; Traber, J.; Kroll, A.; Behra, R.; Sigg, L. Characterization of Extracellular Polymeric Substances (EPS) from Periphyton Using Liquid Chromatography-Organic Carbon Detection-Organic Nitrogen Detection (Lc-Ocd-Ond). Environ. Sci. Pollut. Res. Int. 2013, 20, 3214-3223.

52. Decho, A. W. Microbial Biofilms in Intertidal Systems: An Overview. Cont. Shelf Res. 2000, 20, 1257-1273.

53. Wustman, B. A.; Gretz, M. R.; Hoagland, K. D. Extracellular Matrix Assembly in Diatoms (Bacillariophyceae) (I. A Model of Adhesives Based on Chemical Characterization and Localization of Polysaccharides from the Marine Diatom Achnanthes Longipes and Other Diatoms). Plant Physiol. 1997, 113, 1059-1069.

54. Czamara, K.; Majzner, K.; Pacia, M. Z.; Kochan, M. Z.; Kaczor, A.; Baranska, M. Raman Spectroscopy of Lipids: A Review. J. Raman Spectrosc. 2015, 46, 4-20.

55. Rygula, A.; Majzner, K.; Marzec, K. M.; Kaczor, A.; Pilarczyk, M.; Baranska, M. Raman Spectroscopy of Proteins: A Review. J Raman Spectrosc. 2013, 44, 1061-1076.

56. Wiercigroch, E.; Szafraniec, E.; Czamara, K.; Pacia, M. Z.; Majzner, K.; Kochan, K.; Kaczor, A.; Baranska, M.; Malek, K. Raman and Infrared Spectroscopy of Carbohydrates: A Review. Spectrochim. Acta A Mol. Biomol. Spectrosc. 2017, 185, 317-335.

57. Wu, H.; Volponi, J. V.; Oliver, A. E.; Parikh, A. N.; Simmons, B. A.; Singh, S. In Vivo Lipidomics Using Single-Cell Raman Spectroscopy. Proc. Natl. Acad. Sci. USA. 2011, 108, 3809-3814.

58. Kumar, V.; Kashyap, M.; Gautam, S.; Shukla, P.; Joshi, K. B.; Vinayak, V. Fast Fourier Infrared Spectroscopy to Characterize the Biochemical Composition in Diatoms. J. Biosci. 2018, 43, 717-729.

59. Biswas, R. K.; Khan, P.; Mukherjee, S.; Mukhopadhyay, A. K.; Ghosh, J.; Muraleedharan, K. Study of Short Range Structure of Amorphous Silica from Pdf Using Ag Radiation in Laboratory Xrd System, Raman and Nexafs. J. Non-Cryst. Solids 2018, 488, 1-9. 
60. Rüger, J.; Unger, N.; Schie, I. W.; Brunner, E.; Popp, J.; Krafft, C. Assessment of Growth Phases of the Diatom Ditylum brightwellii by Ft-Ir and Raman Spectroscopy. Algal Res. 2016, 19, 246-252.

61. Yuan, P.; He, H. P.; Wu, D. Q.; Wang, D. Q.; Chen, L. J. Characterization of Diatomaceous Silica by Raman Spectroscopy. Spectrochim. Acta A Mol. Biomol. Spectrosc. 2004, 60, 29412945.

62. Gügi, B.; Le Costaouec, T.; Burel, C.; Lerouge, P.; Helbert, W.; Bardor, M. Diatom-Specific Oligosaccharide and Polysaccharide Structures Help to Unravel Biosynthetic Capabilities in Diatoms. Mar. Drugs 2015, 13, 5993-6018.

63. Loustau, E.; Ferriol, J.; Koteiche, S.; Gerlin, L.; Leflaive, J.; Moulin, F.; Girbal-Neuhauser, E.; Rols, J. L. Physiological Responses of Three Mono-Species Phototrophic Biofilms Exposed to Copper and Zinc. Environ. Sci. Pollut. Res. 2019, 26, 11-14.

64. Kilham, S. S.; Kreeger, D. A.; Lynn, S. G.; Goulden, C. E.; Herrera, L. Combo: A Defined Freshwater Culture Medium for Algae and Zooplankton. Hydrobiologia 1998, 377, 147-159. 


\section{Figures legends}

Figure 1. AFM imaging reveals the ultrastructure of $\boldsymbol{N}$. palea diatom cells. Low (a, e) and high $(b, c, f, g)$ resolution deflection images of $N$. palea cells deposited on hydrophobic substrates. Images were acquired using peak force tapping mode in air (a-c) and in COMBO medium (e-g). The white arrow in $f$ indicates the raphe. $(d, h)$ Vertical cross sections taken in the corresponding height images, i.e. images a, plain line and c, dashed line for sections in d; and images e, plain line and $\mathrm{g}$, dashed line for sections in h. Similar data were obtained in multiple experiments using different AFM tips and cell cultures.

Figure 2. Microscale analysis of $\boldsymbol{N}$. palea adhesion. Optical microscopy images (phase contrast) showing the adhesion behaviour of $N$. palea on hydrophobic (left) and hydrophilic (right) substrates. Insets correspond to images from a duplicate experiment.

Figure 3. Single-cell force spectroscopy and chemical force microscopy to decipher diatom adhesion. (a) Zoomed and large scale optical images of a single N. palea cell (black arrow) attached at the apex of tipless cantilevers (left) before force measurements on hydrophobic and hydrophilic surfaces (right). (b) AFM tri-dimensional image of $N$. palea cell immobilized on a hydrophobic surface (left) before force volume mapping (black mesh) with AFM tips functionalized with hydrophobic or hydrophilic groups (right).

Figure 4. Single-cell analysis reveals strong adhesion of $\boldsymbol{N}$. palea cells on hydrophobic surfaces. Maximum adhesion force and rupture length histograms together with representative adhesive profiles obtained by recording multiple force-distance curves ( $\mathrm{n}$ > 200 for each cell) between single N. palea cells attached on tipless cantilevers and hydrophobic (a) or hydrophilic surfaces (b). The adhesion on hydrophobic surfaces was stronger than on hydrophilic surfaces and presented multiple peaks on the force-distance signatures. ( 6 cells from 4 independent experiments are presented). 
Figure 5. Hyperadhesive $N$. palea cells adhere on both hydrophobic and hydrophilic surfaces as revealed by SCFS. Maximum adhesion force and rupture length histograms together with representative adhesive profiles obtained by recording multiple force-distance curves ( $n>200$ for each cell) between single N. palea cells attached on tipless cantilevers and hydrophobic (a) or hydrophilic surfaces (b). In the case of hyperadhesive phenotypes, cells presented adhesion towards both hydrophobic and hydrophilic surfaces. (2 cells from 2 independent experiments are presented).

Figure 6. Some $\boldsymbol{N}$. palea cells present non-adhesive phenotypes as revealed by SCFS. Maximum adhesion force and rupture length histograms together with representative adhesive profiles obtained by recording multiple force-distance curves ( $n>200$ for each cell) between single $N$. palea cells attached on tipless cantilevers and hydrophobic (a) or hydrophilic surfaces (b). For non-adhesive cells, almost no adhesive events were recorded on both hydrophobic and hydrophilic surfaces. 2 cells from 2 independent experiments are presented).

Figure 7. Chemical force spectroscopy analysis of $\boldsymbol{N}$. palea cell surface. (a, c, e, g) Adhesion force maps $\left(2 \times 2 \mu \mathrm{m}^{2} ; z\right.$ range $\left.=1 \mathrm{nN}\right)$ recorded with hydrophobic $(\mathrm{a}, \mathrm{c})$ or hydrophilic tips $(e, g)$ at the surface of $N$. palea cells maintained in COMBO buffer. (b, $d, f, h)$ Corresponding adhesion force and rupture length histograms $(n=1024)$ with representative force curves. Adhesion frequency was higher with hydrophobic tips and force curves presented multiple peaks. For each condition, 2 cells from independent experiments with different tips are presented.

Figure 8. Raman spectra of $\boldsymbol{N}$. palea cells in COMBO medium. Spectra from 6 different areas on an individual cell (bottom) and on a cell aggregate (top) are presented. The spectrum corresponding to aggregated cells was $y$-shifted for clarity. Key: $v$, stretching; $\delta$, bending; $\tau$, twisting; a, antisymmetric; s, symmetric; Phe, phenylalanine; TAG, triacylglycerol. 
Figure 1
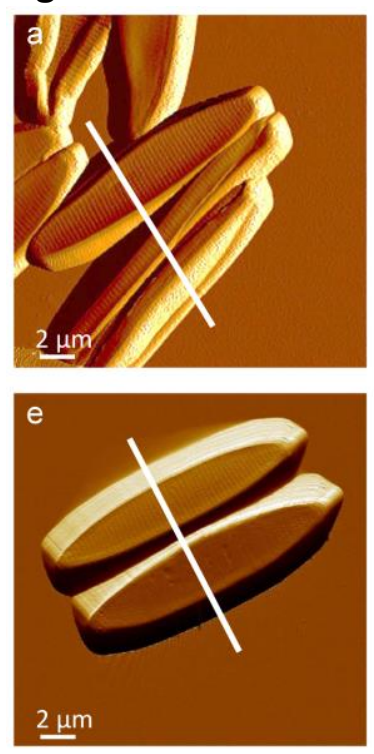
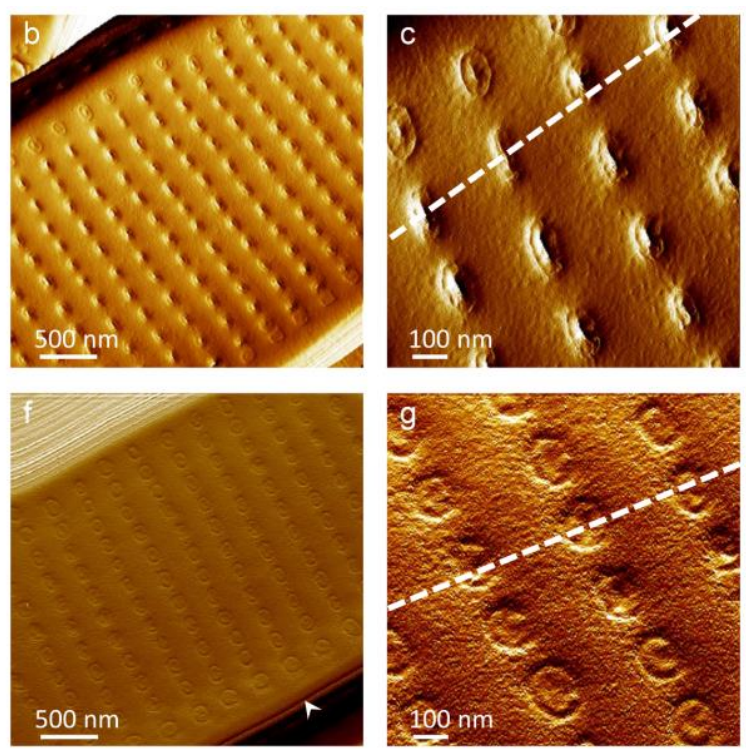
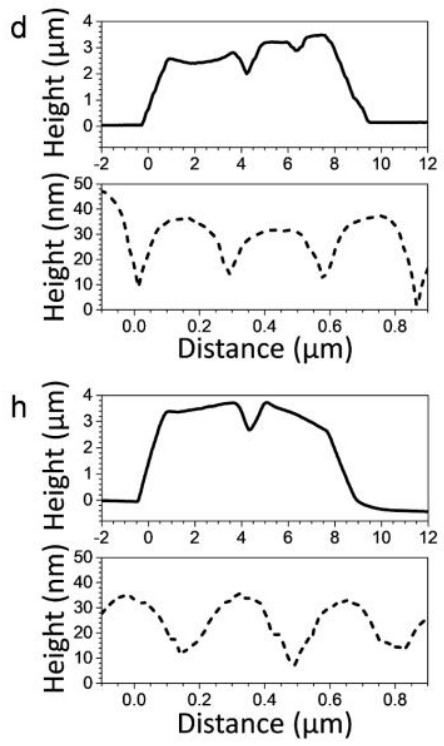
Figure 2

Hydrophobic

Hydrophilic

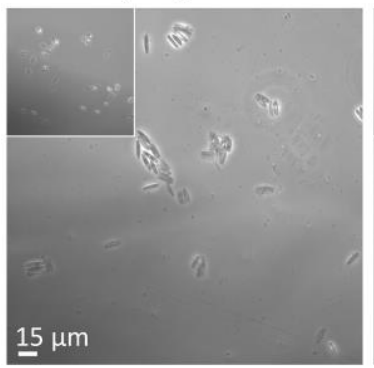

$15 \mu \mathrm{m}$

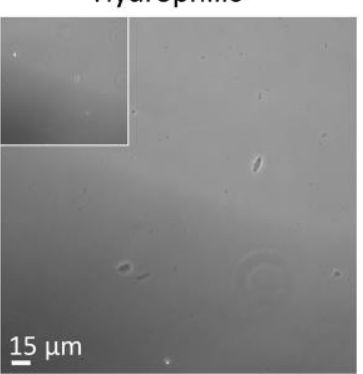

Laviale et al. 


\section{Figure 3}

a

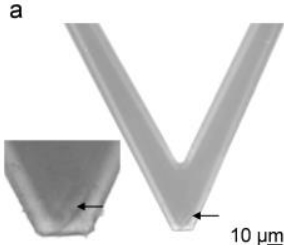

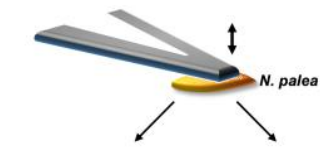

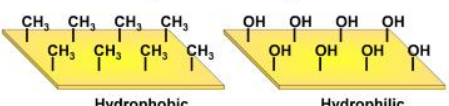

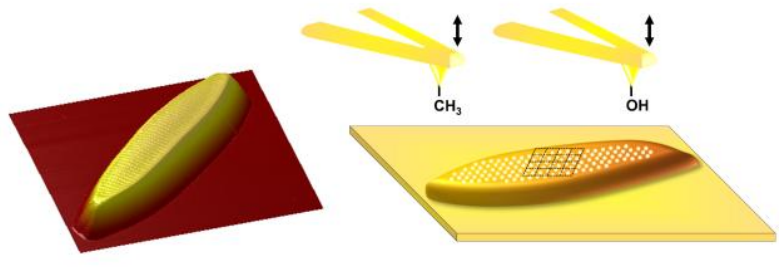




\section{Figure 4}
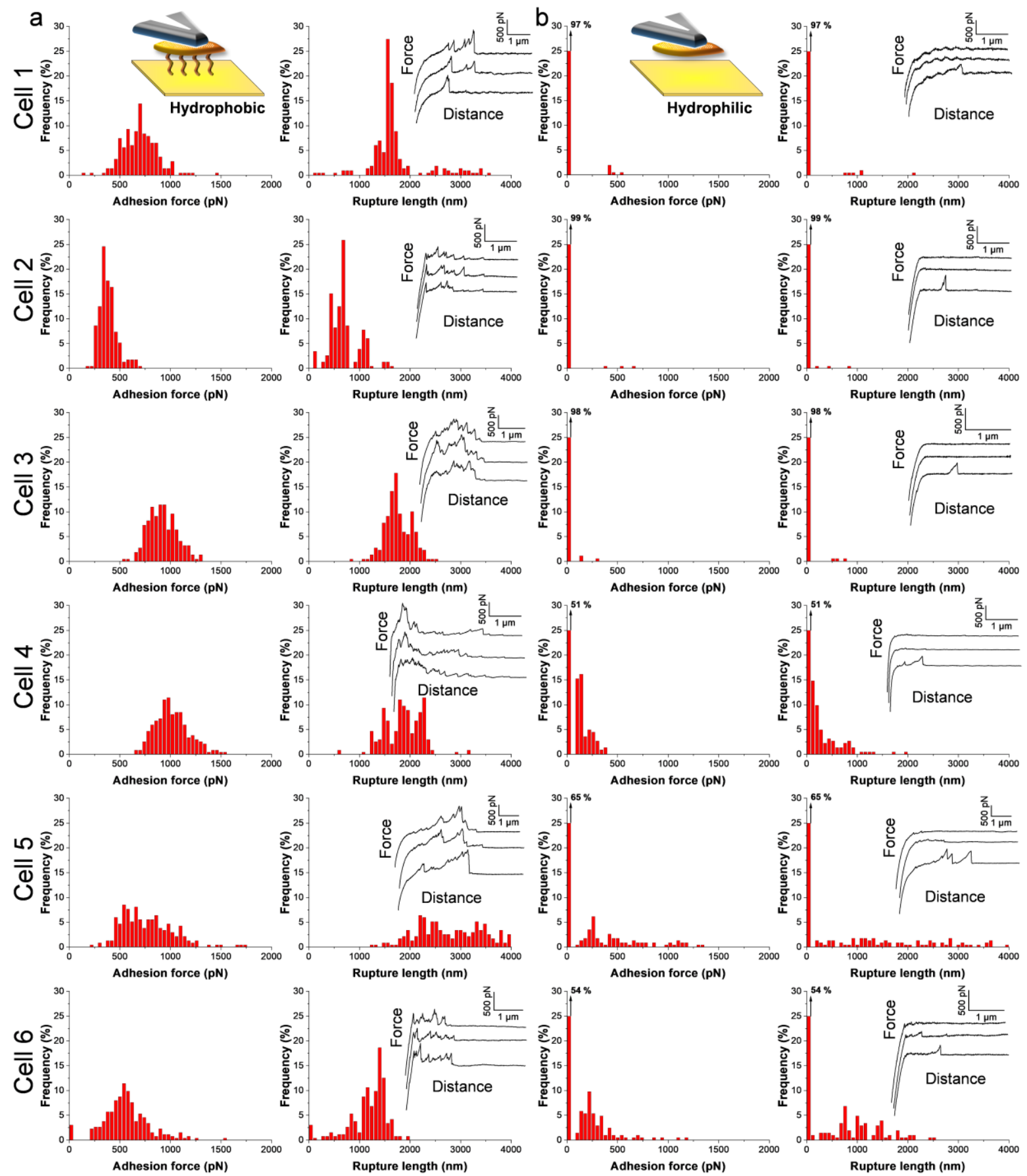
26

Figure 5
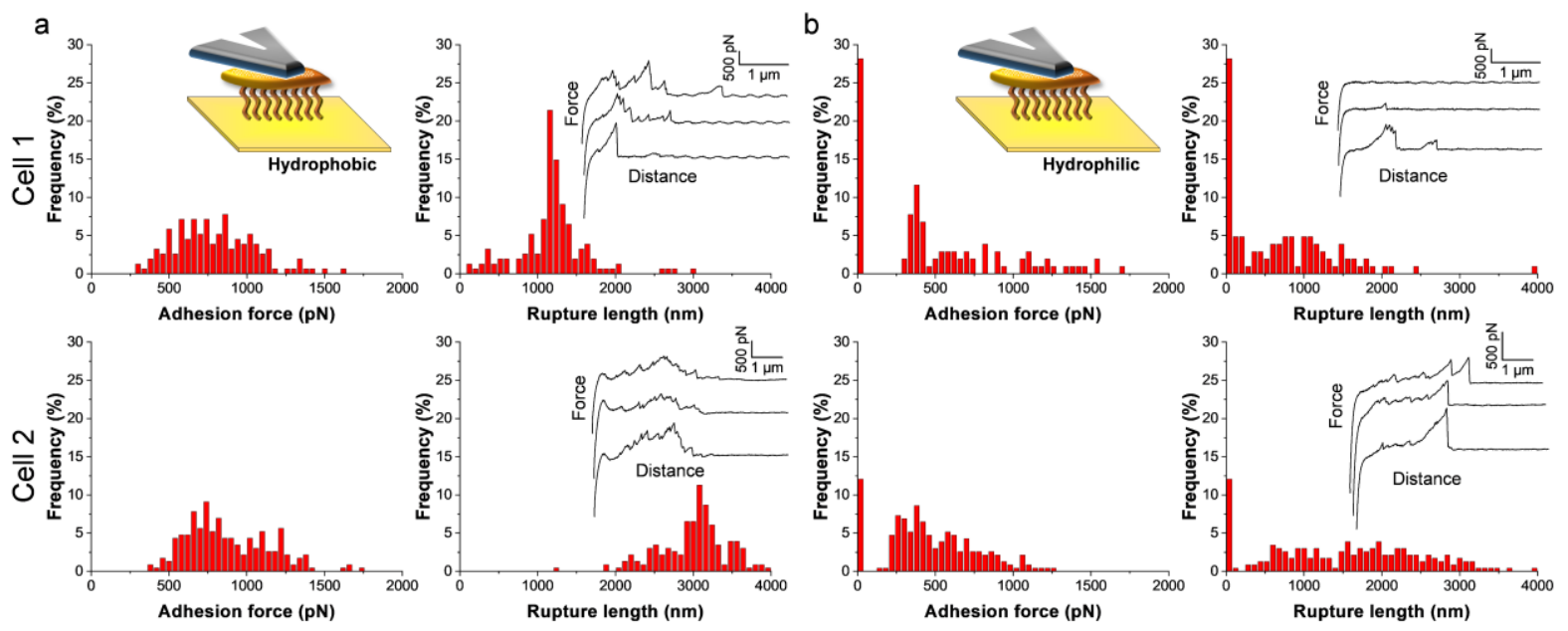

Laviale et al. 
Figure 6
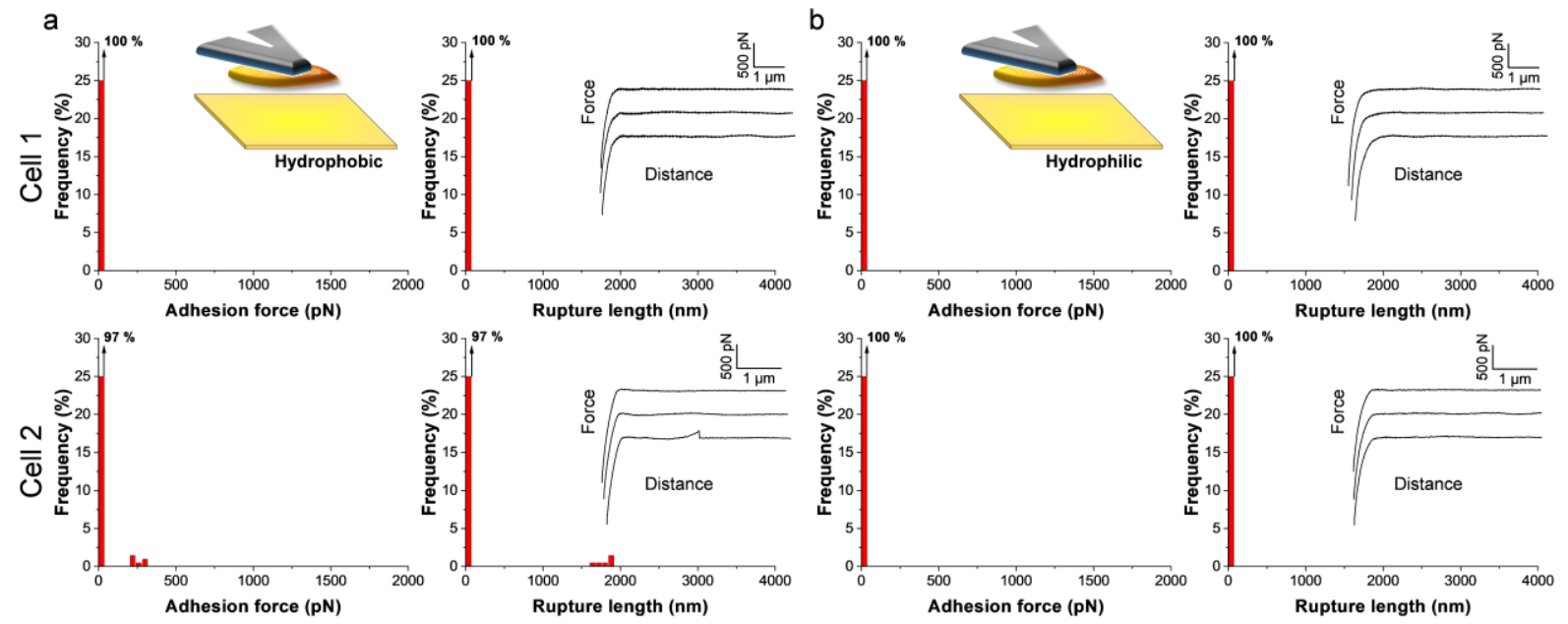
Figure 7

a
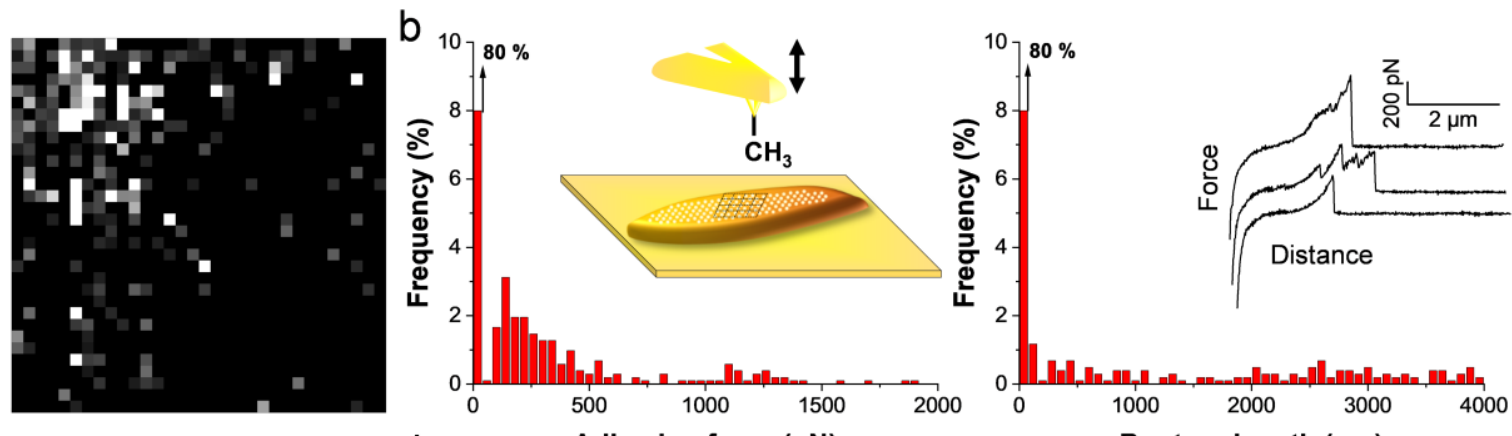

C
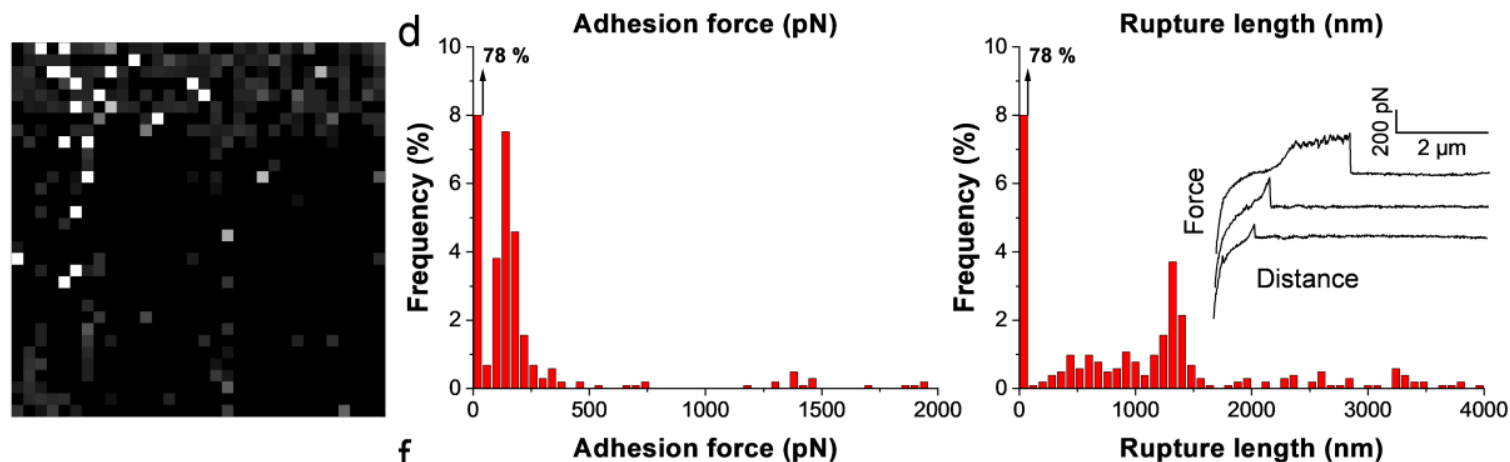

e
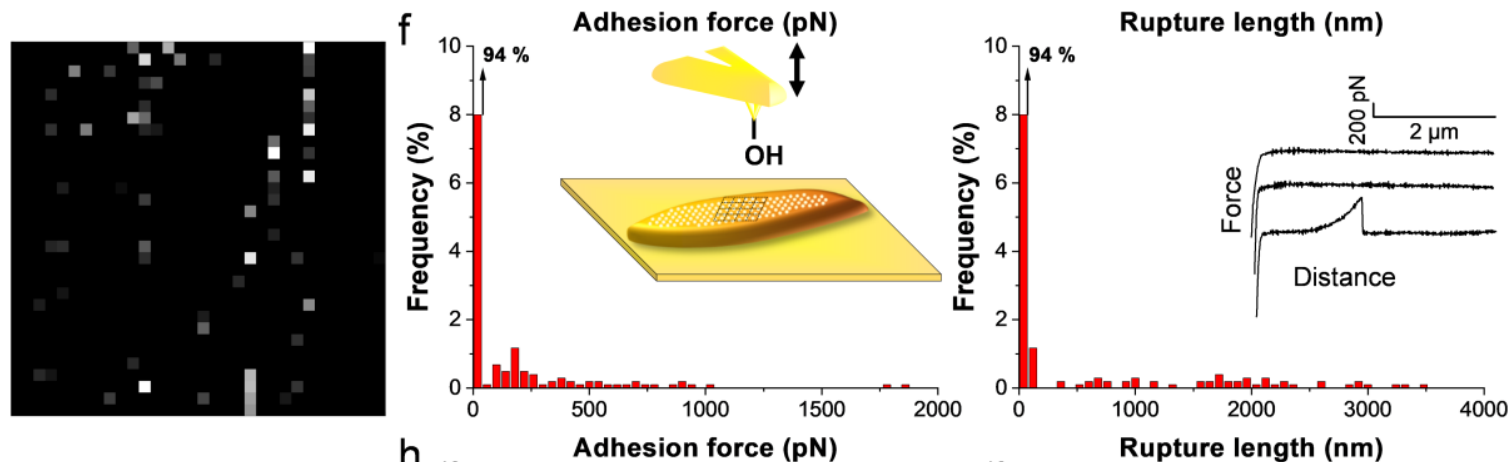

g

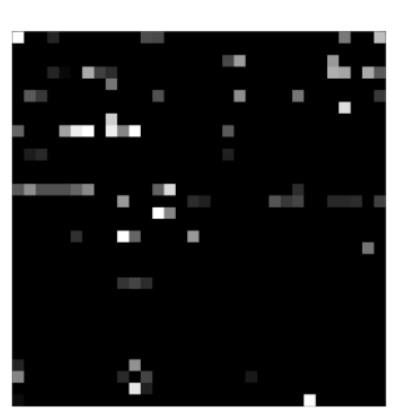

h ${ }_{10} 792 \%$

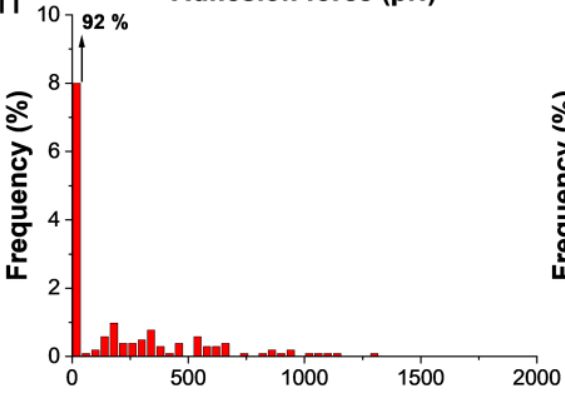

Adhesion force (pN)

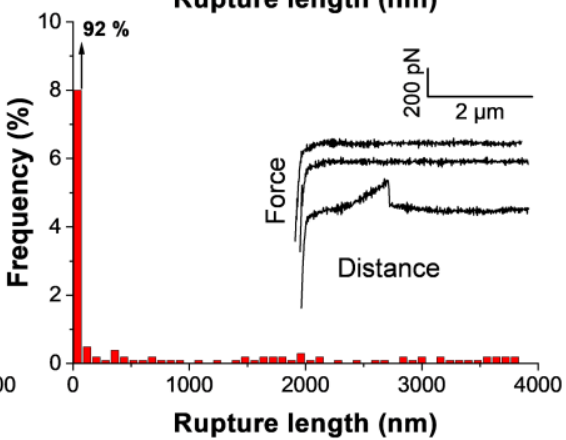


Figure 8

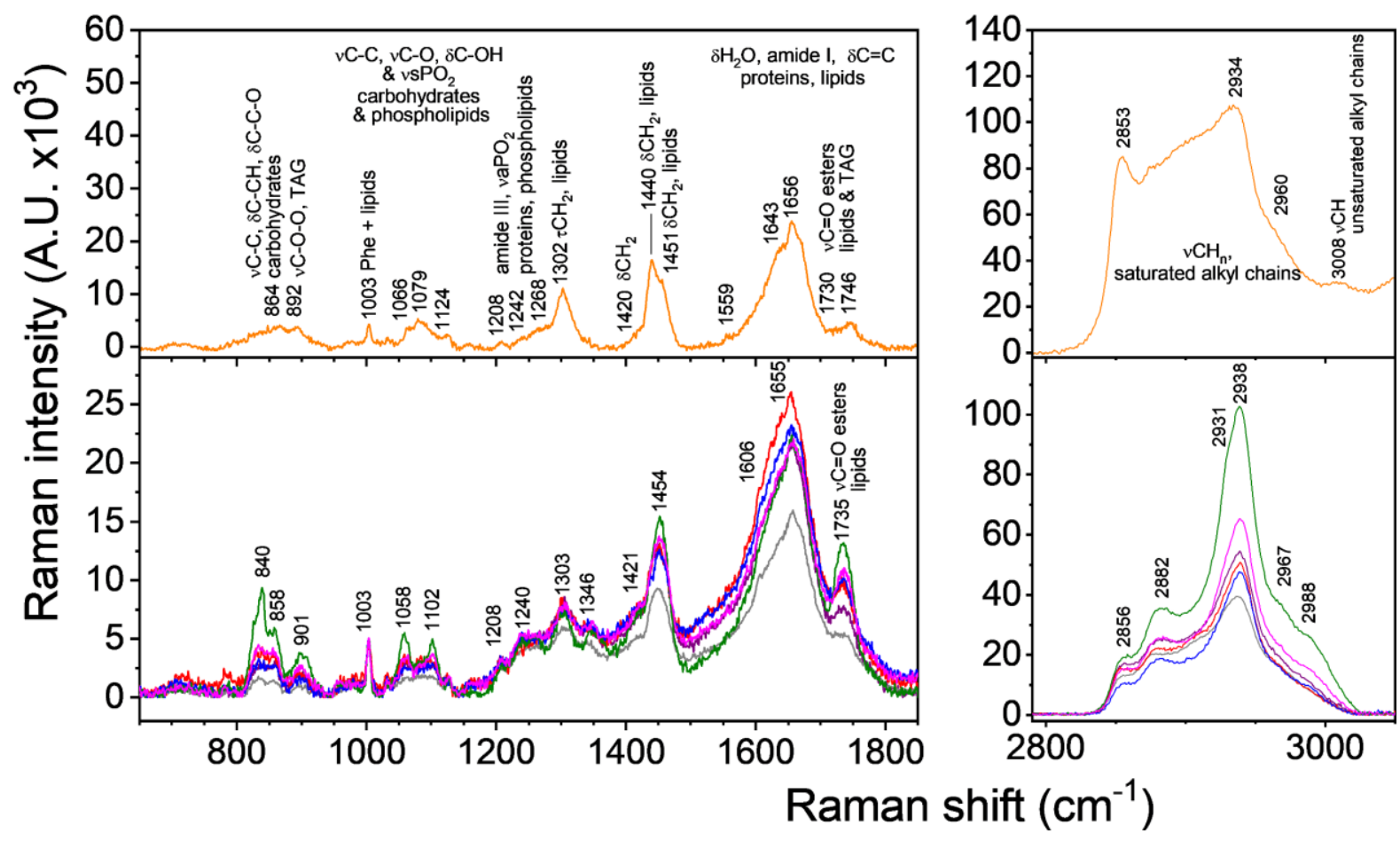


Figure S1
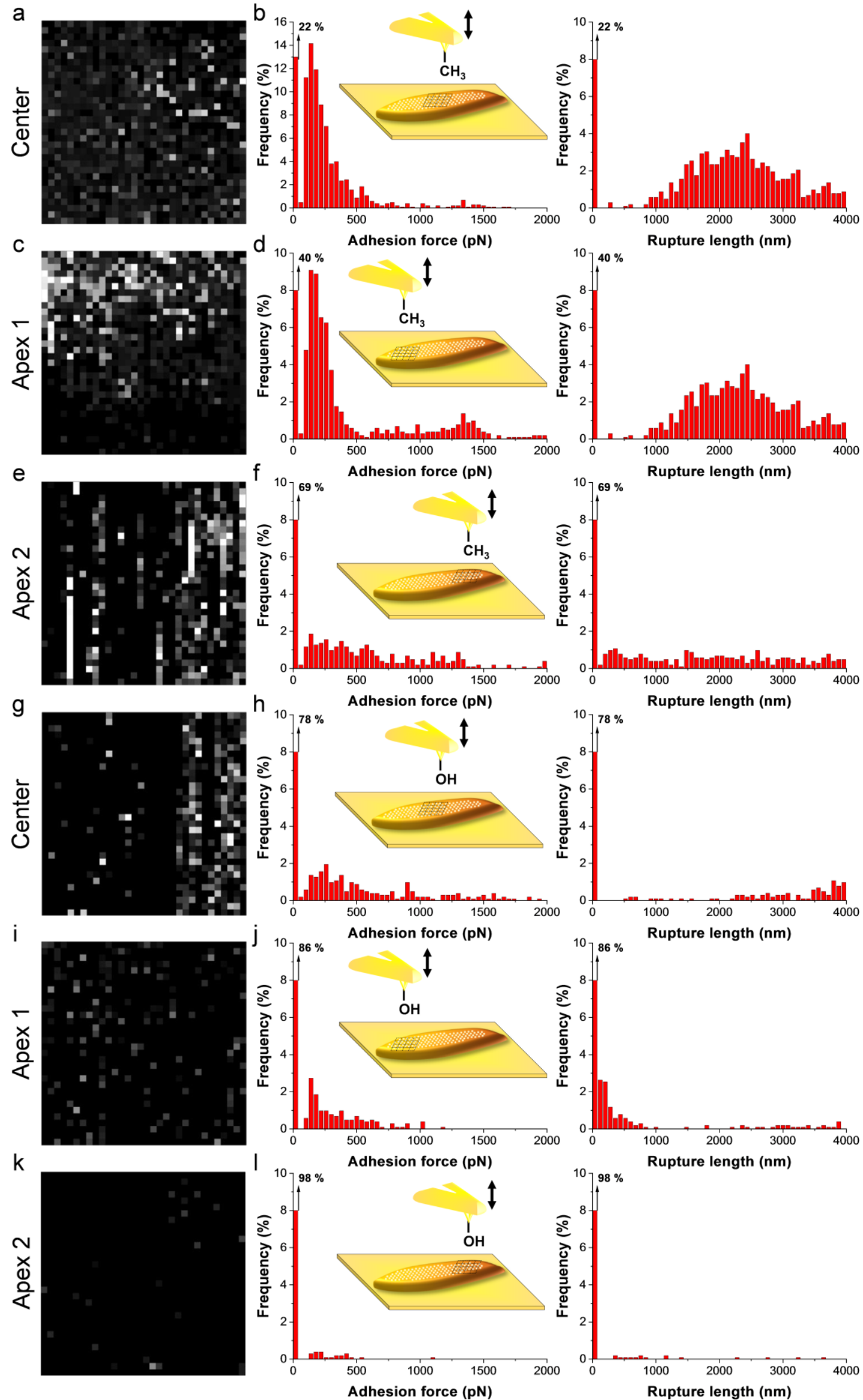
ToC
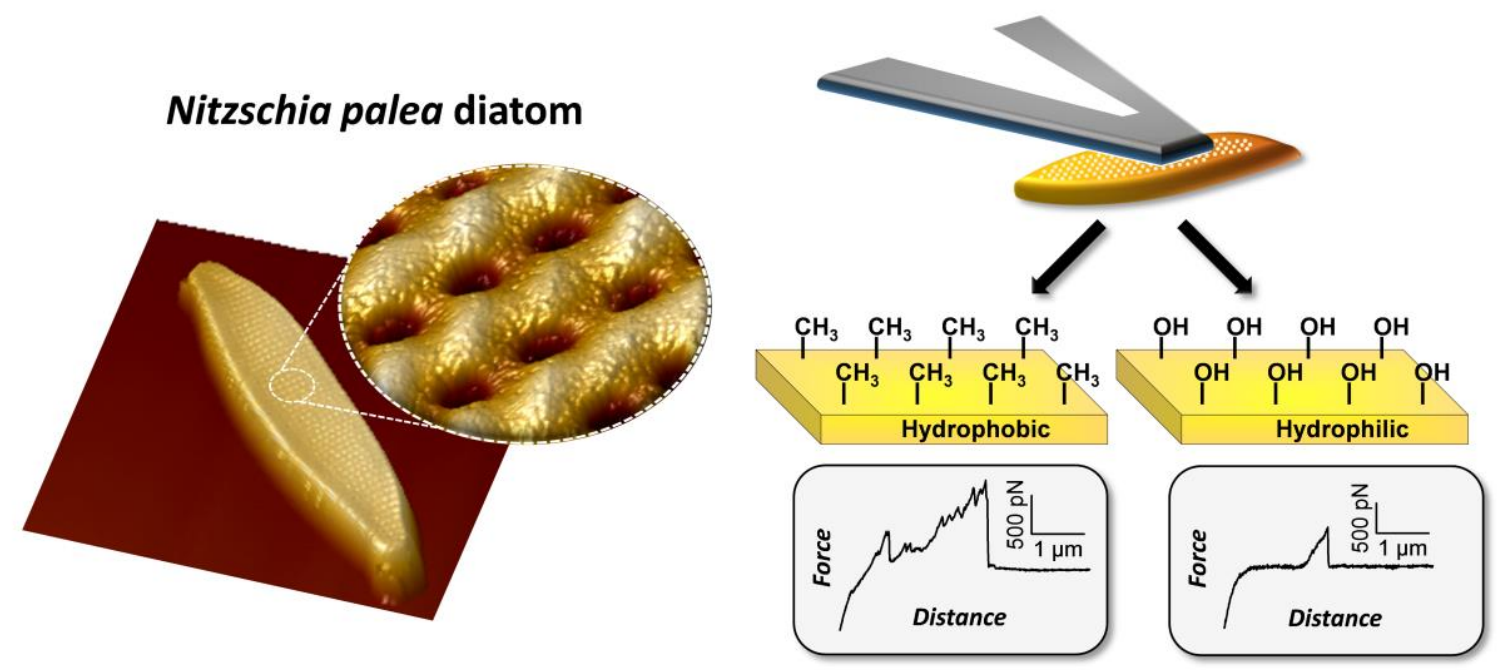